\title{
COMPOSITIONAL ANALYSIS OF THE SEWAGE INCOMING TO AND DISCHARGED FROM THE SEWAGE TREATMENT PLANT IN KOLBUSZOWA DOLNA
}

\author{
Krzysztof Chmielowski ${ }^{1}$, Piotr Bugajski ${ }^{1}$, Grzegorz Kaczor ${ }^{1}$ \\ 1 University of Agriculture in Kraków, Al. Mickiewicza 24/28, 30-059 Kraków, Poland, e-mail: k.chmielowski@ \\ ur.krakow.pl
}

Received: 2016.08.11

Accepted: 2016.09.26

Published: 2016.11.01

\section{INTRODUCTION}

Poland's accession in the European Union involved its commitment to comply with applicable laws on water and sewage management. The essential framework document on the subject is the Waste Directive. Based on this document, Poland has developed its National Programme for Municipal Waste Treatment [KPOŚK 2003]. It states that agglomerations with population equivalent (PE) of at least 2000 must have collective sewerage systems discharging the sewage into wastewater treatment plants (WTP) (Miernik and Młyński 2014a; Miernik and Młyński 2014b; Chmielowski et al. 2015). The Program has been updated several times and its master plan has been developed recently. The document comprises assorted data summaries for agglomerations of PE

\begin{abstract}
The paper presents the compositional analysis of sewage supplied to and discharged from the wastewater treatment plant in Kolbuszowa Dolna in the Subcarpathian region. The analysis was based on three basic indicators of sewage pollution $\left(\mathrm{BOD}_{5}, \mathrm{COD}_{\mathrm{Cr}}\right.$, total suspended solids) and two biogenic indicators (total nitrogen and total phosphorus). The composition of sewage was studied in the years 2010-2015. Basic descriptive the following indicators were presented: $\mathrm{COD} / \mathrm{BOD}, \mathrm{BOD} / \mathrm{N}, \mathrm{BOD} / \mathrm{P}$. The collected results indicate high variability of the composition of sewage entering the studied of the collected material showed that sewage entering the treatment $\mathrm{plant}$ was readily biodegradable. On the other hand, the treated sewage was characterized by low values of the analyzed indicators, much below the permissible values provided by the water permit. The raw sewage was divided into five groups depending on the concentration of each pollution indicator. The number of raw sewage samples was determined for
\end{abstract} $>2000$. The document enables the assessment of
$>$ dation, wastewater treatment plant sewage composion progress in the construction of new wastewater treatment plants and modernization of existing ones. The size of agglomerations is also referred to in the Regulation [2014]. The document comprises a Table stating the permissible values of pollution indicators for sewage incoming from agglomerations of various sizes. It is worth noting that, according to the provisions of the Waste Directive, Poland recognized an obligation to ensure good condition of its waters by the end of 2015. Most of the work has been done already, although some of the postulations still remain to be completed. Therefore, all efforts should be made to improve the composition of sewage discharged by agglomerations in our country. Efficient sewage systems are required so that sewage can be 
discharged into collective wastewater treatment plants (Mikołajczyk and Krajewski 2014).

\section{STUDY SCOPE AND OBJECTIVES}

The aim of this research work was to analyze the values of pollution indicators for the incoming and discharged sewage for the WTP in Kolbuszowa Dolna in the Subcarpathian region. The analysis was based on three key sewage pollution indicators $\left(\mathrm{BOD}_{5}, \mathrm{COD}_{\mathrm{Cr}}\right.$, total suspended solids) and two biogenic indicators (total nitrogen and total phosphorus). The compositional analysis of sewage was performed in the years 2010-2015. Basic descriptive statistics for the values of the analyzed indicators of sewage pollution were summarized and the results were interpreted. The study also shows that raw sewage is susceptible to biological treatment. Descriptive statistics for the relationships between the following indicators are shown: $\mathrm{COD}_{\mathrm{Cr}} / \mathrm{BOD}_{5}, \mathrm{BOD}_{5} / \mathrm{N}_{\text {tot }}, \mathrm{BOD}_{5} /$ $\mathrm{P}_{\text {tot }}$. Moreover, the raw sewage was divided into five categories, depending on the concentration of specific pollution indicators. The number of the raw sewage samples was determined in each group for the analyzed pollution indicators.

\section{DESCRIPTION OF THE STUDY OBJECT}

The WTP is located in Kolbuszowa Dolna near Rzeszów in the Subcarpathian region. It is a mechanical and biological plant with an integrated system designed to eliminate nitrogen and phosphorus. Sewage arrives in the WTP from a combined sewerage system. After treatment, the sewage is discharged into the stream named Nil - a quaternary, right-bank tributary of the stream Przyrwa which, in turn, flows into the river Łęg - a right-bank tributary of the Vistula. According to the water permit [Water Permit 2009], it is permissible to discharge treated sewage in the amount of $\mathrm{Q}_{\text {mean }}=3600 \mathrm{~m}^{3} \cdot \mathrm{d}^{-1}$ or less into the receiving water body. The values of the sewage components being discharged into a receiving water body may not exceed the following values: $\mathrm{BOD}_{5}-25 \mathrm{mg} \mathrm{O}_{2} \cdot \mathrm{dm}^{-3}, \mathrm{COD}_{\mathrm{Cr}}-125 \mathrm{mg} \mathrm{O} \cdot \mathrm{dm}^{-3}$ and total suspended solids $-35 \mathrm{mg} \cdot \mathrm{dm}^{-3}$.

In simple terms, the WTP is composed of a mechanical part (fine-bar screen and sand trap) and a biological part (biological reactor and ra- dial secondary settling tanks). Figure 1 shows a simplified flow sheet for the WTP in Kolbuszowa Dolna. The essential part of it - the biological reactor - comprises several chambers, where predenitrification, dephosphatation, nitrification, and denitrification processes take place. The design solution enables high-efficiency treatment with a simultaneous removal of biogenic compounds. The water permit is valid till 31.12.2019.

\section{MATERIALS AND METHODS}

An analysis of the values of pollution indicators for the incoming raw sewage and for that discharged into the receiving water body after treatment is discussed in this paper. Sewage samples were collected once a month as required by applicable standards (PN-74/C-04620/11, PN-EN 25667-2:1999). The indicators were determined as follows: $\mathrm{BOD}_{5}-$ manometric method, $\mathrm{COD}_{\mathrm{Cr}}$ - dichromate method, total suspended solids - directly by weighing, total nitrogen and total phosphorus - by spectrophotometry. The sewage samples were tested by an accredited laboratory. A total of 259 measurement series were performed (for raw sewage and for treated sewage), during which a total of 518 sewage samples were tested. Based on the test results, the efficacy of reduction of the pollution indicators was determined using the following equation.

$$
\eta=\frac{X_{d o p}-X_{o d p}}{X_{\text {dop }}} \cdot 100[\%]
$$

where: $X_{\text {inc }}-$ value of pollution indicator for raw sewage $\left[\mathrm{mg} \cdot \mathrm{dm}^{-3}\right]$, $X_{\text {dis }}$ - value of pollution indicator for treated sewage $\left[\mathrm{mg} \cdot \mathrm{dm}^{-3}\right]$,

The following basic descriptive statistics were established for the analyzed pollution indicators of raw sewage and treated sewage: mean value $(\bar{X})$, median $\left(\mathrm{m}_{\mathrm{e}}\right)$, minimum value $\left(\mathrm{X}_{\min }\right)$, maximum value $\left(\mathrm{X}_{\max }\right)$, standard deviation $(\sigma)$, coefficient of variation $\left(\mathrm{V}_{\mathrm{var}}\right)$, range $\left(\mathrm{R}_{\mathrm{o}}\right)$. An attempt was made to assess the biodegradability of raw sewage by defining its basic descriptive statistics for the ratios of values of selected pollution indicators: $\mathrm{COD}_{\mathrm{Cr}} / \mathrm{BOD}_{5}, \mathrm{BOD}_{5} / \mathrm{N}_{\text {tot }}, \mathrm{BOD}_{5} /$ $\mathrm{P}_{\text {tot }}$. The raw sewage was divided into categories with respect to its concentrations of the pollution indicators. Ranges of individual intervals were determined based on the reports by Henze $[1982,1992,2002]$. Taking into account the 


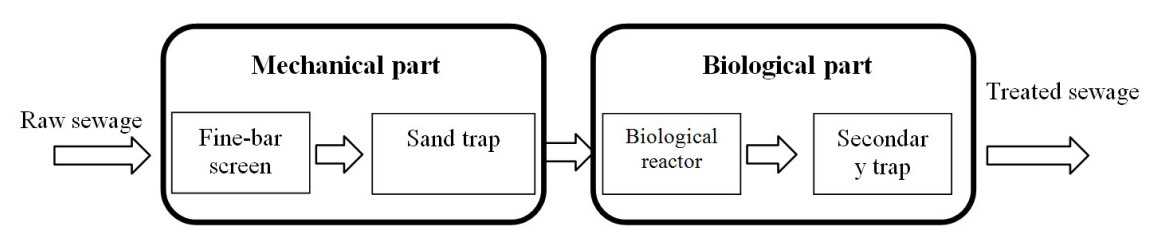

Figure 1. Simplified flow sheet for the wastewater treatment plant in Kolbuszowa Dolna

compositions of the sewage, five main categories were established: I - highly concentrated, II - concentrated, III - moderately concentrated, IV - diluted, V - highly diluted. The sewage categories accounted for the following pollution indicators: $\mathrm{BOD}_{5}, \mathrm{COD}_{\mathrm{Cr}}$, total suspended solids, total phosphorus and total nitrogen. The percentages of test samples belonging in each sewage category were determined.

\section{RESULTS AND DISCUSSION}

At the first stage of the study, the values of the pollution indicators for the raw sewage entering the WTP in Kolbuszowa Dolna were analyzed. Table 1 shows the basic descriptive statistics of pollution indicators for the raw sewage.

The data in Table 1 indicate that the mean value of $\mathrm{BOD}_{5}$ for raw sewage was not very high $\left(242.4 \mathrm{mgO}_{2} \mathrm{dm}^{-3}\right)$. For the purpose of division into sewage concentration categories, it falls in group III - moderately concentrated sewage. Standard deviation at $111.3 \mathrm{mgO}_{2} \cdot \mathrm{dm}^{-3}$ may imply a significant compositional variability of the incoming sewage. This is attributable to the contribution of infiltration and incidental waters, having low values of $\mathrm{BOD}_{5}$. The problem was reported earlier, by other authors [Kaczor 2006,
Kaczor 2009, Kaczor 2011, Kaczor et al. 2013]. On the other hand, high values of that indicator are attributable to liquid sewage arriving in vacuum tanks. For that kind of sewage, the values of pollution indicators are typically very high. The range of values of BOD5 was high $-835.0 \mathrm{mgO}_{2}$. $\mathrm{dm}^{-3}$ over the entire test period.

Another indicator $-\mathrm{COD}_{\mathrm{Cr}}$ - was, on average, $561.9 \mathrm{mgO}_{2} \mathrm{dm}^{-3}$ which means that, for the purpose of division into sewage concentration categories, it falls in group III - moderately concentrated sewage. Its value was highly varied, with the range of $1742.0 \mathrm{mgO}_{2} \cdot \mathrm{dm}^{-3}$. A similar phenomenon was reported by other authors [Krzanowski and Wałęga 2004, Sikorski 1989, Sikorski 1994a, Sikorski 1994b].

The concentration of total suspended solids in raw sewage was, on average, $272.6 \mathrm{mg} \cdot \mathrm{dm}^{-3}$, indicating that the parameter falls in group III of sewage concentration. The content of biogenic indicators (total nitrogen, total phosphorus) was also analyzed and it was found that mean concentration of total nitrogen was $44.6 \mathrm{mgN}_{\text {tot }} \mathrm{dm}^{-3}$ and that of total phosphorus was $7.7 \mathrm{mgP}$ tot $\mathrm{dm}^{-3}$. This means that mean concentrations of biogenic indicators were in group III (moderately concentrated sewage). According to the available literature [Bugajski and Bergel 2008, Jóźwiakowski and Pytka 2010, Chmielowski et al. 2012], the raw sewage

Table 1. Basic descriptive statistics for pollution indicators of raw sewage flowing into the treatment plant in Kolbuszowa Dolna

\begin{tabular}{|c|c|c|c|c|c|c|}
\hline \multirow[b]{2}{*}{ Descriptive statistics } & \multirow[b]{2}{*}{ Symbol } & \multicolumn{5}{|c|}{ Sewage pollution indicator } \\
\hline & & $\begin{array}{c}\mathrm{BOD}_{5} \\
{\left[\mathrm{mgO}_{2} \cdot \mathrm{dm}^{-3}\right]}\end{array}$ & $\begin{array}{c}\mathrm{COD}_{\mathrm{Cr}} \\
{\left[\mathrm{mgO}_{2} \cdot \mathrm{dm}^{-3}\right]}\end{array}$ & $\begin{array}{c}\text { Total } \\
\text { suspended } \\
\text { solids } \\
{\left[\mathrm{mg} \cdot \mathrm{dm}^{-3}\right]}\end{array}$ & $\begin{array}{l}\text { Total nitrogen } \\
{\left[\mathrm{mgN}_{\text {tot }} \cdot \mathrm{dm}^{-3}\right]}\end{array}$ & $\begin{array}{c}\text { Total } \\
\text { phosphorus } \\
{\left[\mathrm{mgP}_{\text {tot }} \cdot \mathrm{dm}^{-3}\right]}\end{array}$ \\
\hline Mean value & $\bar{X}$ & 242.4 & 561.9 & 272.6 & 44.6 & 7.7 \\
\hline Median & $m_{e}$ & 210.0 & 508.0 & 245.0 & 44.1 & 7.3 \\
\hline Minimum value & $X_{\min }$ & 49.0 & 108.0 & 89.0 & 12.2 & 1.3 \\
\hline Maximum value & $\mathrm{X}_{\operatorname{Max}}$ & 884.0 & 1850.0 & 990.0 & 112.5 & 28.0 \\
\hline Standard deviation & $\sigma$ & 111.3 & 252.3 & 124.7 & 14.7 & 3.1 \\
\hline Coefficient of variation & $\mathrm{V}_{\mathrm{var}}$ & 0.46 & 0.45 & 0.46 & 0.33 & 0.40 \\
\hline Range & $\mathrm{R}_{\mathrm{o}}$ & 835.0 & 1742.0 & 901.0 & 100.3 & 26.7 \\
\hline Number of samples & $\mathrm{N}$ & 259 & 259 & 259 & 259 & 259 \\
\hline
\end{tabular}


entering the WTP in Kolbuszowa Dolna is a typical domestic sewage, characterized by high variability of the values of their pollution indicators.

Table 2 presents concentrations of selected pollution indicators in raw sewage. Henze [2002] categorized raw sewage into four main groups: highly concentrated, moderately concentrated, diluted, highly diluted.

Considering the concentration of individual pollution indicators, more detailed categories of sewage pollution were adopted in this study. Table 3 presents our categories of raw sewage depending on its pollution concentration. Ranges of individual intervals were determined based on the reports by Henze [1982, 1992, 2002]. The sewage was divided into five basic groups: I - highly con- centrated, II - concentrated, III - moderately concentrated, IV - diluted, V - highly diluted. The sewage groups accounted for the following pollution indicators: $\mathrm{BOD}_{5}, \mathrm{COD}_{\mathrm{Cr}}$, total suspended solids, total phosphorus and total nitrogen.

Table 4 shows the number of samples of raw sewage in various concentration groups.

The data in Table 4 indicate that, as far as the value of $\mathrm{BOD}_{5}$ is concerned, the incoming sewage was dominated by the moderately concentrated group (32.8\%) in contrast to the strongly concentrated group, for which the percentage was the lowest at $3.9 \%$. For $\mathrm{COD}_{\mathrm{Cr}}$ it was found that group IV - diluted sewage (32.1\%) was dominant, and group V - highly diluted sewage (6.9\%) was the least frequent. As regards total suspended solids,

Table 2. Concentration of selected pollution indicators in raw urban sewage [Henze 1982, Henze 1992, Henze 2002, Odegaard 1992]

\begin{tabular}{|l|c|c|c|c|c|}
\hline \multirow{2}{*}{ Indicator } & \multirow{2}{*}{ Unit } & \multicolumn{4}{c|}{ Sewage concentration } \\
\cline { 3 - 6 } & & Concentrated & Moderately concentrated & Diluted & Highly diluted \\
\hline $\mathrm{BOD}_{5}$ & $\mathrm{mgO}_{2} \cdot \mathrm{dm}^{-3}$ & 350 & 250 & 150 & 100 \\
\hline $\mathrm{COD}_{\mathrm{Cr}}$ & $\mathrm{mgO}_{2} \cdot \mathrm{dm}^{-3}$ & 740 & 530 & 320 & 210 \\
\hline Total suspended solids & $\mathrm{mg} \cdot \mathrm{dm}^{-3}$ & 450 & 300 & 190 & 120 \\
\hline Total nitrogen & $\mathrm{mgN}_{\text {tot }} \mathrm{dm}^{-3}$ & 80 & 50 & 30 & 20 \\
\hline Total phosphorus & $\mathrm{mgP}_{\text {tot }} \cdot \mathrm{dm}^{-3}$ & 14 & 10 & 6 & 4 \\
\hline
\end{tabular}

Table 3. Categories of raw sewage according to the concentration of investigated pollution indicators (authors' own work)

\begin{tabular}{|l|c|c|c|c|c|}
\hline \multirow{2}{*}{\multicolumn{1}{|c|}{ Indicator }} & \multicolumn{4}{c|}{ Raw sewage concentration categories } \\
\cline { 2 - 6 } & $\begin{array}{c}\text { Category I } \\
\text { highly } \\
\text { concentrated }\end{array}$ & $\begin{array}{c}\text { Category II } \\
\text { concentrated }\end{array}$ & $\begin{array}{c}\text { Category III } \\
\text { moderately } \\
\text { concentrated }\end{array}$ & $\begin{array}{c}\text { Category IV } \\
\text { diluted }\end{array}$ & $\begin{array}{c}\text { Category V } \\
\text { highly diluted }\end{array}$ \\
\hline $\mathrm{BOD}_{5}$ & $\mathrm{x}_{\mathrm{i}} \geq 450$ & $450>\mathrm{x}_{\mathrm{i}} \geq 300$ & $300>\mathrm{x}_{\mathrm{i}} \geq 200$ & $200>\mathrm{x}_{\mathrm{i}} \geq 125$ & $\mathrm{x}_{\mathrm{i}}<125$ \\
\hline $\mathrm{COD}_{\mathrm{Cr}}$ & $\mathrm{x}_{\mathrm{i}} \geq 800$ & $800>\mathrm{x}_{\mathrm{i}} \geq 635$ & $635>\mathrm{x}_{\mathrm{i}} \geq 425$ & $425>\mathrm{x}_{\mathrm{i}} \geq 265$ & $\mathrm{x}_{\mathrm{i}}<265$ \\
\hline Total suspended solids & $\mathrm{x}_{\mathrm{i}} \geq 500$ & $500>\mathrm{x}_{\mathrm{i}} \geq 375$ & $375>\mathrm{x}_{\mathrm{i}} \geq 245$ & $245>\mathrm{x}_{\mathrm{i}} \geq 155$ & $\mathrm{x}_{\mathrm{i}}<155$ \\
\hline Total nitrogen & $\mathrm{x}_{\mathrm{i}} \geq 90$ & $90>\mathrm{x}_{\mathrm{i}} \geq 65$ & $65>\mathrm{x}_{\mathrm{i}} \geq 40$ & $40>\mathrm{x}_{\mathrm{i}} \geq 25$ & $\mathrm{x}_{\mathrm{i}}<25$ \\
\hline Total phosphorus & $\mathrm{x}_{\mathrm{i}} \geq 16$ & $16>\mathrm{x}_{\mathrm{i}} \geq 12$ & $12>\mathrm{x}_{\mathrm{i}} \geq 8$ & $8>\mathrm{x}_{\mathrm{i}} \geq 5$ & $\mathrm{x}_{\mathrm{i}}<5$ \\
\hline
\end{tabular}

Table 4. Number of samples of raw sewage in different groups of concentrations of the analyzed pollution indicators in the treatment plant in Kolbuszowa Dolna

\begin{tabular}{|c|c|c|c|c|c|c|c|c|c|c|}
\hline \multirow{3}{*}{ Indicator } & \multicolumn{10}{|c|}{$\begin{array}{l}\text { Number of samples of raw sewage and their percentages } \\
\text { in different groups of concentration }\end{array}$} \\
\hline & \multicolumn{2}{|c|}{$\begin{array}{l}\text { Category I } \\
\text { highly } \\
\text { concentrated }\end{array}$} & \multicolumn{2}{|c|}{$\begin{array}{l}\text { Category II } \\
\text { concentrated }\end{array}$} & \multicolumn{2}{|c|}{$\begin{array}{l}\text { Category III } \\
\text { moderately } \\
\text { concentrated }\end{array}$} & \multicolumn{2}{|c|}{$\begin{array}{l}\text { Category IV } \\
\text { diluted } \\
\text { sewage }\end{array}$} & \multicolumn{2}{|c|}{$\begin{array}{c}\text { Category V } \\
\text { highly } \\
\text { diluted sewage }\end{array}$} \\
\hline & {$[\mathrm{pc}]$} & {$[\%]$} & {$[\mathrm{pc}]$} & {$[\%]$} & {$[\mathrm{pc}]$} & {$[\%]$} & {$[\mathrm{pc}]$} & {$[\%]$} & {$[\mathrm{pc}]$} & {$[\%]$} \\
\hline $\mathrm{BOD}_{5}$ & 10 & 3.9 & 63 & 24.3 & 85 & 32.8 & 74 & 28.6 & 27 & 10.4 \\
\hline $\mathrm{COD}_{\mathrm{Cr}}$ & 40 & 15.4 & 47 & 18.1 & 71 & 27.5 & 83 & 32.1 & 18 & 6.9 \\
\hline Total suspended solids & 12 & 4.6 & 32 & 12.4 & 87 & 33.6 & 97 & 37.4 & 31 & 12.0 \\
\hline Total nitrogen & 2 & 0.8 & 15 & 5.8 & 148 & 57.2 & 76 & 29.3 & 18 & 6.9 \\
\hline Total phosphorus & 5 & 1.9 & 13 & 5.0 & 101 & 39.0 & 112 & 43.3 & 28 & 10.8 \\
\hline
\end{tabular}


groups III and IV were dominant, constituting a total of $71 \%$ of all the sewage samples. In the case of total nitrogen, group III was dominant (57.2\%). As regards total phosphorus in the incoming sewage, group IV of diluted sewage prevailed.

Figure 2 shows mean values of $\mathrm{COD}_{\mathrm{Cr}} / \mathrm{BOD}_{5}$ ratio for each month in the years 2010-2015.

Figure 2 presents mean values of $\mathrm{COD}_{\mathrm{Cr}} / \mathrm{BOD}_{5}$ ratio for each month in the years 2010-2015. They indicate that the sewage entering the WTP in Kolbuszowa Dolna was readily biodegradable. According to Henze [2002], ratios $\mathrm{COD} / \mathrm{BOD}_{5}>$ 2 mean that the sewage is readily biodegradable. The highest mean value of $\mathrm{COD} / \mathrm{BOD}_{5}$ ratio was observed in October (2.45), whereas the lowest ratios were recorded for November and December.

Figure 3 shows mean values of $\mathrm{BOD}_{5} /$ $\mathrm{N}_{\text {tot }}$ in raw sewage for each month in the years 2010-2015.

The data in Figure 3 indicate that the sewage entering the WTP in Kolbuszowa Dolna tends to have a favorable $\mathrm{BOD}_{5}$ /total nitrogen ratio for most months. According to literature [Henze 2002], the ratio $\mathrm{BOD}_{5} / \mathrm{N}_{\text {tot }}$ should preferably be higher than 5. Values of $\mathrm{BOD}_{5} / \mathrm{N}_{\text {tot }}$ lower than 5 were recorded for February (4.6), March (4.7), and July (4.8). They were slightly lower than the recommended value of 5.0. This means that $\mathrm{BOD}_{5} / \mathrm{N}_{\text {tot }}$ ratio was favorable for most of the raw sewage, thus enabling efficient removal of total nitrogen from the sewage.

Figure 4 shows mean values of $\mathrm{BOD}_{5} /$ $\mathrm{P}_{\text {tot }}$ in raw sewage for each month in the years 2010-2015.

Table 5 shows basic descriptive statistics for pollution indicators of treated sewage discharged from the WTP in Kolbuszowa Dolna.

The data in Table 5 indicate that the values of $\mathrm{BOD}_{5}$ were very low - on average $3.5 \mathrm{mgO}_{2} \cdot \mathrm{dm}^{-3}$, compared with the permissible maximum of $25 \mathrm{mgO}_{2} \cdot \mathrm{dm}^{-3}$. Even the maximum value that was recorded for all the 259 samples collected and analyzed did not exceed the permissible maximum and was as low as $7.7 \mathrm{mgO}_{2} \mathrm{dm}^{-3}$. This reflects very well on the processes taking place in the WTP, in particular in the multi-chamber reactor. The range between the minimum and the maximum values for that indicator was low - merely $7.5 \mathrm{mgO}_{2} \cdot \mathrm{dm}^{-3}$; also low was the value of standard deviation $\left(1.1 \mathrm{mgO}_{2} \cdot \mathrm{dm}^{-3}\right)$, indicating that the op-

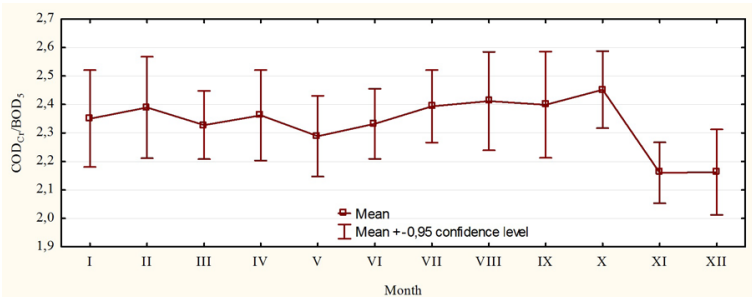

Figure 2. Mean values of $\mathrm{COD}_{\mathrm{Cr}} / \mathrm{BOD}_{5}$ ratio for each month in the years 2010-2015

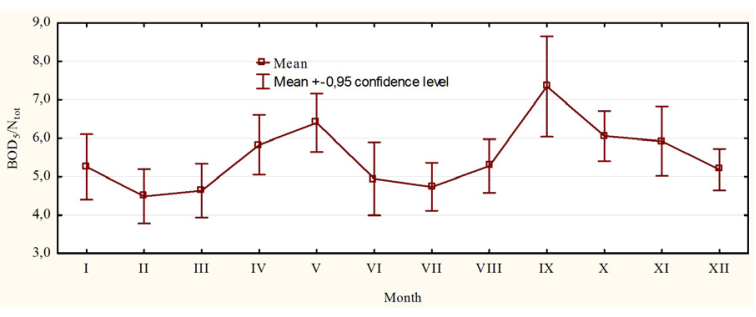

Figure 3. Mean values of $\mathrm{BOD}_{5} / \mathrm{N}_{\text {tot }}$ in raw sewage for each month in the years 2010-2015

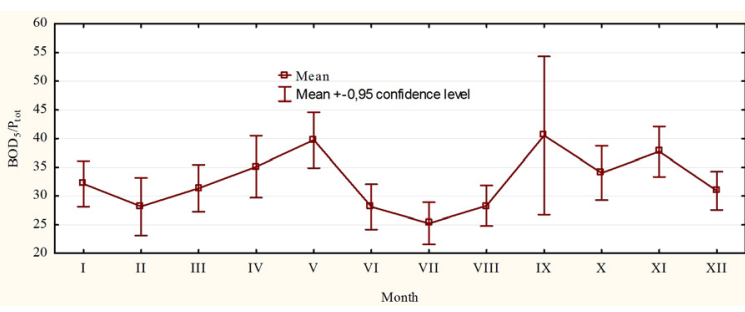

Figure 4. Mean values of $\mathrm{BOD}_{5} / \mathrm{P}_{\text {tot }}$ in raw sewage for each month in the years 2010-2015

eration of the WTP was very smooth and stable. The same observation was made for the second indicator: $\mathrm{COD}_{\mathrm{Cr}}$ of which the mean value was 37.5 $\mathrm{mgO}_{2} \mathrm{dm}^{-3}$. Also in this case, the maximum permissible value $\left(125 \mathrm{mgO}_{2} \cdot \mathrm{dm}^{-3}\right)$ was not exceeded and the actual maximum was $75.0 \mathrm{mgO}_{2} \cdot \mathrm{dm}^{-3}$.

Total suspended solids was the third value analyzed in this study. Its mean value was 4.6 $\mathrm{mg} \cdot \mathrm{dm}^{-3}$. As in the case of oxygen-related indicators, the maximum permissible value $\left(35 \mathrm{mg}^{-\mathrm{dm}^{-3}}\right)$ was not exceeded for total suspended solids and the maximum was recorded at $13.0 \mathrm{mg} \cdot \mathrm{dm}^{-3}$.

Biogenic indicators were also analyzed, in addition to the basic ones. For total nitrogen, the maximum permissible value $\left(15 \mathrm{mgN}_{\text {tot }} \cdot \mathrm{dm}^{-3}\right)$ was slightly exceeded. Its maximum for the analyzed period was $18.9 \mathrm{mgN}_{\text {tot }} \mathrm{dm}^{-3}$. Its mean value was $8.7 \mathrm{mgN}_{\text {tot }} \mathrm{dm}^{-3}$, i.e., $58 \%$ of the permissible maximum. Elevated values of total nitrogen in treated sewage were recorded mainly for winter months 
Table 5. Basic descriptive statistics for pollution indicators of treated sewage discharged from the treatment plant in Kolbuszowa Dolna

\begin{tabular}{|c|c|c|c|c|c|c|}
\hline \multirow[b]{2}{*}{ Descriptive statistics } & \multirow[b]{2}{*}{ Symbol } & \multicolumn{5}{|c|}{ Sewage pollution indicator } \\
\hline & & $\begin{array}{c}\mathrm{BOD}_{5} \\
{\left[\mathrm{mgO}_{2} \cdot \mathrm{dm}^{-3}\right]}\end{array}$ & $\begin{array}{c}\mathrm{COD}_{\mathrm{Cr}} \\
{\left[\mathrm{mgO}_{2} \cdot \mathrm{dm}^{-3}\right]}\end{array}$ & $\begin{array}{c}\text { Total } \\
\text { suspended } \\
\text { solids } \\
{\left[\mathrm{mg} \cdot \mathrm{dm}^{-3}\right]}\end{array}$ & $\begin{array}{l}\text { Total nitrogen } \\
{\left[\mathrm{mgN}_{\text {tot }} \cdot \mathrm{dm}^{-3}\right]}\end{array}$ & $\begin{array}{c}\text { Total } \\
\text { phosphorus } \\
{\left[\mathrm{mgP}_{\text {tot }} \mathrm{dm}^{-3}\right]}\end{array}$ \\
\hline Mean value & $\bar{X}$ & 3.5 & 37.5 & 4.6 & 8.7 & 0.5 \\
\hline Median & $m_{e}$ & 3.5 & 38.0 & 4.5 & 8.2 & 0.4 \\
\hline Minimum value & $X_{\min }$ & 0.2 & 13.5 & 2.0 & 1.3 & 0.1 \\
\hline Maximum value & $X_{\operatorname{Max}}$ & 7.7 & 75.0 & 13.0 & 18.9 & 1.4 \\
\hline Standard deviation & $\sigma$ & 1.1 & 8.7 & 1.2 & 2.7 & 0.3 \\
\hline Coefficient of variation & $\mathrm{V}_{\mathrm{var}}$ & 0.30 & 0.23 & 0.25 & 0.31 & 0.60 \\
\hline Range & $\mathrm{R}_{0}$ & 7.50 & 61.50 & 11.00 & 17.65 & 1.31 \\
\hline Number of samples & $\mathrm{N}$ & 259 & 259 & 259 & 259 & 259 \\
\hline Permissible value & $X_{\text {per }}$ & 25 & 125 & 35 & 15 & 2 \\
\hline
\end{tabular}

(from December to March), characterized by low air temperatures. This is clearly seen in Figure 6, showing mean values of total nitrogen in the respective months in the years 2010-2015. The bacteria involved in nitrification and denitrification processes are sensitive to low temperatures.

Figure 5 shows mean concentrations of total nitrogen in treated sewage for each month in the years 2010-2015. The values were lower in the summer months (July and August) and higher in the winter (December, January, February, March). This is attributable to lower temperatures of the air, potentially affecting the intensity of nitrification and denitrification processes. The temperature of sewage in the winter may fall as low as -10 ${ }^{\circ} \mathrm{C}$, which may eventually stop the processes connected with the elimination of nitrogen from sewage. The lowest concentration of total nitrogen in the treated sewage was recorded for August and July - the months with the highest air temperatures (the mean was $7.2 \mathrm{mgN}_{\text {tot }} \mathrm{dm}^{-3}$ and $7.8 \mathrm{mgN}$ ${ }_{\text {tot }} \mathrm{dm}^{-3}$, respectively). The highest values of total nitrogen in the treated sewage were calculated for February and March (mean $9.8 \mathrm{mgN}_{\mathrm{tot}} \mathrm{dm}^{-3}$ ). When analyzing the cases where the permissible values for treated sewage were exceeded, it was found to have occurred in the winter months. It is postulated that, in order to improve the efficiency of elimination of total nitrogen, the biological reactor should be made hermetic, potentially resulting in the sewage temperature being reduced by as much as several degrees Celsius.

Figure 6 shows mean concentrations of total phosphorus in treated sewage for each month in the years 2010-2015. The maximum for total phosphorus was not higher than $0.8 \mathrm{mgP}_{\text {tot }} \mathrm{dm}^{-3}$. This shows that the dephosphatation process runs correctly and is aided by chemical precipitation, reducing the value of total phosphorus even further.

\section{CONCLUSIONS}

An analysis of values of pollution indicators of the incoming and treated sewage for the wastewater treatment plant in Kolbuszowa Dolna in the Subcarpathian region is presented in this paper. The percentage of samples of raw sewage in each analyzed group with respect to its concentration

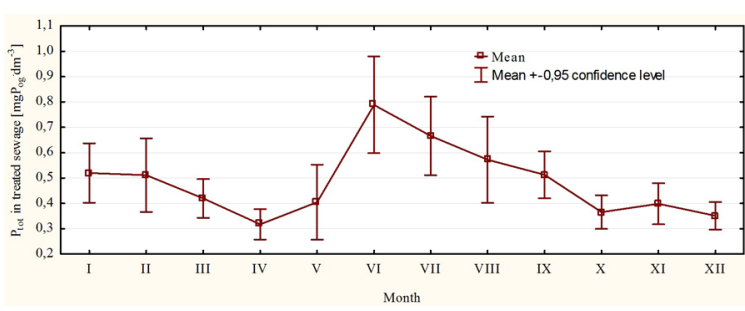

Figure 6. Mean values of total phosphorus for each month in the years 2010-2015 
of pollution indicators was determined. The results of the analyses indicate that:

1. Raw sewage arriving in the WTP in Kolbuszowa Dolna from the sewerage system was characterized by different values of its pollution indicators. This is shown by the ranges of values for each indicator that were high: BOD5 - 835.0 $\mathrm{mgO}_{2} \cdot \mathrm{dm}^{-3}$, CODCr - 1742.0 $\mathrm{mgO}_{2} \cdot \mathrm{dm}^{-3}$, total suspended solids -901.0 $\mathrm{mg} \cdot \mathrm{dm}^{-3}$, total nitrogen $-100.3 \mathrm{mgN}_{\text {tot }} \cdot \mathrm{dm}^{-3}$ and total phosphorus $-26.7 \mathrm{mgP}_{\text {tot }} \cdot \mathrm{dm}^{-3}$. The wide range of values for the analyzed indicators in raw sewage is attributable to the fact that incidental or infiltration waters enter the sewerage system and tend to dilute domestic sewage, but also to extremely high values of pollution indicators, which may be due to the presence of liquid sewage arriving in vacuum tanks.

2. Mean values of the analyzed indicator in the raw sewage were as follows: $\mathrm{BOD}_{5}-242.4$ $\mathrm{mgO}_{2} \cdot \mathrm{dm}^{-3}, \mathrm{COD}_{\mathrm{Cr}}-561.9 \mathrm{mgO}_{2} \cdot \mathrm{dm}^{-3}$, total suspended solids $-272.6 \mathrm{mg} \cdot \mathrm{dm}^{-3}$, total nitrogen $-44.6 \mathrm{mgN}_{\text {tot }} \mathrm{dm}^{-3}$ and total phosphorus $7.7 \mathrm{mgP}_{\text {tot }} \mathrm{dm}^{-3}$. They are comparable to those reported in the literature on domestic sewage.

3. Taking into consideration the concentration of raw sewage, the predominant groups were: group III (moderately concentrated sewage) in the case of $\mathrm{BOD}_{5}$ and total nitrogen, and group IV (diluted sewage) in the case of $\mathrm{COD}_{\mathrm{Cr}}$, total suspended solids and total phosphorus. In general, the diluted and strongly diluted sewage groups had very high percentages of raw sewage samples for each pollution indicator $\left(\mathrm{BOD}_{5}\right.$ and $\mathrm{COD}_{\mathrm{Cr}} 39 \%$ each, total suspended solids $-49 \%$, total nitrogen $-36.2 \%$ and total phosphorus $-54.1 \%$ ).

4. Total nitrogen concentration in the treated sewage in the analyzed period was variable, depending on which month of the year was considered: the lowest values were recorded for the summer months (July, August), and the highest for the winter months (from December to March). This is attributable to the air temperature which, when low, was capable of slowing down the nitrification and denitrification processes taking place in the reactor. It is postulated that, in future, the biological reactor should be made hermetic by means of plastic elements: they will enable the sewage temperature to be kept somewhat higher during the winter months and will also help reduce odor nuisance in the immediate vicinity of the treatment plant. The solution has already been implemented in the WTP in Połaniec and its preliminary results seem to be proving it was justified.

5. Mean values of the analyzed indicators in treated sewage were as follows: $\mathrm{BOD}_{5}-3.5$ $\mathrm{mgO}_{2} \cdot \mathrm{dm}^{-3}, \mathrm{COD}_{\mathrm{Cr}}-37.5 \mathrm{mgO}_{2} \mathrm{dm}^{-3}$, total suspended solids $-4.6 \mathrm{mg} \cdot \mathrm{dm}^{-3}$, total nitrogen $-8.7 \mathrm{mgN}_{\text {tot }} \mathrm{dm}^{-3}$ and total phosphorus -0.5 $\mathrm{mgP} \mathrm{P}_{\text {tot }} \mathrm{dm}^{-3}$. They indicate that the sewage discharged from the WTP in Kolbuszowa Dolna was characterized by low values of pollution indicators, showing that the processes taking place in it were running correctly. Total nitrogen concentration was the only value for which the permissible limit was exceeded by several times in the winter months.

\section{REFERENCES}

1. Bugajski P., Bergel T. 2008. Wielkości wybranych stężeń zanieczyszczeń w ściekach bytowych odpływających z terenów wiejskich. Gaz, Woda i Technika Sanitarna, 9, 28-29.

2. Chmielowski K., Kurek K., Bąk P. 2012. Efektywność oczyszczania ścieków na przykładzie oczyszczalni w Lipnicy Wielkiej. Infrastruktura i Ekologia Terenów Wiejskich, No. 3, p. 213-224.

3. Chmielowski K., Bugajski P., Wąsik E. 2015. Ocena działania oczyszczalni ścieków w Haczowie przed i po modernizacji. Infrastruktura i Ekologia Terenów Wiejskich, nr 4, 949-964.

4. Henze M. 1982. Husspildevands sammensating (The Compostion of Domestic Wastewater). Stadsog Havneingenioren, 73, 386-387, Denmark.

5. Henze M. 1992. Characterization of water for modelling of activated sludge processes. Water Science and Technology, 25, (6), 1-15.

6. Henze M. 2002. Wastewater Treatment. Biological and Chemical Processes. Springer Verlag.

7. Jóźwiakowski K., Pytka A. 2010. Rozwój gospodarki wodno-ściekowej na terenach wiejskich w Polsce w latach 1990-2008. Gospodarka Odpadami Komunalnymi. Monografia Komitetu Chemii Analitycznej PAN. Vol. VI, 31-39:

8. Kaczor G. 2006. Jednostkowe odpływy ścieków z kanalizacji wiejskiej w gminie Koszyce. Infrastruktura i Ekologia Terenów Wiejskich, nr 2, 171-182. 
9. Kaczor G. 2009. Otwory we włazach studzienek kanalizacyjnych jako jedna z przyczyn przedostawania się wód przypadkowych do sieci rozdzielczej. Infrastruktura i Ekologia Terenów Wiejskich, nr 9, 155-163.

10. Kaczor G. 2011. Wpływ wiosennych roztopów śniegu na dopływ wód przypadkowych do oczyszczalni ścieków bytowych. Acta Sci. Pol., Formatio Circumiectus, Vol. 2, 27-34.

11. Kaczor G., Bugajski P., Bergel T. 2013. Zastosowanie metody trójkąta do obliczania objętości wód infiltracyjnych i przypadkowych w kanalizacji sanitarnej. Infrastruktura i Ekologia Terenów Wiejskich, nr 3, 263-274.

12. Krajowy Program Oczyszczania Ścieków Komunalnych / National Programme for Municipal Waste Treatment 2003. Ministerstwo Środowiska. Warszawa.

13. Krzanowski S., Wałęga A. 2004. Ocena niezawodności działania mechaniczno-biologicznej oczyszczalni ścieków dla miasta Dąbrowa Tarnowska. Inżynieria włókiennicza i ochrona środowiska nr 14. ATH. Bielsko-Biała.

14. Miernik W., Młyński D. 2014a. Analiza pracy oczyszczalni ścieków w Krzeszowicach po modernizacji. Episteme, Vol. 29, 303-310.

15. Miernik W., Młyński D. 2014b. Wpływ modernizacji oczyszczalni dla miasta Wadowice na jakość oczyszczonych ścieków.[w:] J. Rak (ed.): Antropogeniczne czynniki wpływu na środowisko przyrodnicze na przykładzie południowo-wschodniej Polski, wschodniej Słowacji i zachodniej Ukrainy, wyd. Muzeum Regionalne im. Adama Fastnachta w Brzozowie, 109-129.

16. Mikołajczyk M., Krajewski P. 2014. Rozwój sieci kanalizacyjnej na terenie gmin wiejskich po- wiatu jeleniogórskiego. Infrastruktura i Ekologia Terenów Wiejskich, nr 2, 307-318.

17. Odegaard, H. 1992. Norwegian Experiences With Chemical Tretment of Raw Wastewater. Presented at "Management of Waste Waters in Coastal Areas", Montpellier, France, 31 March - 2 April, 1992.

18. PN-74/C-04620-11. 1974. Woda i ścieki - Pobieranie próbek - Pobieranie próbek ścieków z otwartych kanałów ściekowych do analizy fizycznej i chemicznej oraz bakteriologicznej.

19. PN-EN 25667-2:1999. Jakość wody - Pobieranie próbek - Wytyczne dotyczące technik pobierania próbek.

20. Water Permit No. OŚ-6223/36/09 of 31 December 2009.

21. Regulation 2014. Regulation of the Minister of Environment of 18 November 2014 concerning the conditions to be met when discharging liquid waste into water or soil, and on substances which are especially harmful to the aquatic life. Journal of Laws Dz.U. 2014 Item 1800.

22. Sikorski M. 1989. Przegląd procesów, metod i urządzeń do oczyszczania ścieków bytowo-gospodarczych możliwych do zastosowania w warunkach wiejskich. Zagadnienia Techniki Sanitarnej Wsi. Oczyszczanie ścieków wiejskich, procesy, urządzenia, eksploatacyjne. Wrocław.

23. Sikorski M. 1994a. Charakterystyka ścieków wiejskich i sposób ich unieszkodliwiania. Wiadomości Melioracyjne i Łąkarskie. Częstochowa.

24. Sikorski M. 1994b. Oczyszczanie i oczyszczalnie w Polsce. Wiadomości Melioracyjne i Łąkarskie, nr 4. 